Non-timber forest products as a source of livelihood diversification for local communities in the Batang Toru Orangutan Conservation Program 



\section{Non-timber forest products as a source of livelihood diversification for local communities in the Batang Toru Orangutan Conservation Program}

Jusupta Tarigan, James M. Roshetko, Endri Martini and Andree Ekadinata

Working Paper 118 


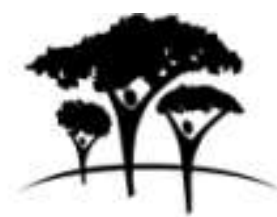

\section{World Agroforestry Centre}

TRANSFORMING LIVES AND LANDSCAPES

\section{Citation}

Tarigan J, Roshetko J.M., Martini E, Ekadinata A. 2010. Non-timber forest products as a source of livelihood diversification for local communities in the Batang Toru Orangutan Conservation Program. Working paper 118. Bogor, Indonesia: World Agroforestry Centre (ICRAF) Southeast Asia Program.

Titles in the Working Paper Series disseminate interim results on agroforestry research and practices and stimulate feedback from the scientific community. Other publication series from the World Agroforestry Centre include agroforestry perspectives, technical manuals and occasional papers.

Published by

World Agroforestry Centre (ICRAF)

Southeast Asia Regional Program

PO Box 161, Bogor 16001, Indonesia

Tel: +62 2518625415

Fax: +622518625416

Email: icraf-indonesia@cgiar.org

http://www.worldagroforestrycentre.org/sea

(C) World Agroforestry Centre 2010

Working Paper 118

\section{Disclaimer and copyright}

The views expressed in this publication are those of the author(s) and not necessarily those of the World Agroforestry Centre. Articles appearing in this publication may be quoted or reproduced without charge, provided the source is acknowledged. All images remain the sole property of their source and may not be used for any purpose without written permission of the source. 


\section{About the authors}

Jusupta Tarigan is a forestry and livelihoods specialist with more than ten years of professional experience in Indonesia in both research and development. He is interested in identifying and creating integrated-development approaches that enable local stakeholders to sustainably manage resources to meet rural communities' livelihoods objectives and governments' environmental goals.

Contact: j.tarigan@ cgiar.org

James M. Roshetko is a natural resource specialist with Winrock International, secondered to ICRAF. He has 30 years of professional experience, including 13 years in South and Southeast Asia, 14 of them being in Indonesia. His work, including both research and development, has focused on identifying and developing integrated-development approaches that enable local stakeholders to sustainably manage resources to meet both rural communities' livelihood objectives and governments' environmental goals. Building viable partnerships of farmers, non-government organizations, government agencies and private sector enterprises has been a key component of this successful work.

Contact: j.roshetko@cgiar.org

Endri Martini is a forester with her main research interest being in multistakeholder perspectives and negotiations in balancing the trade-offs between biodiversity conservation and livelihoods enhancement. She was involved as an agroforestry tree specialist in the USAID-funded Sumatran orangutan conservation program in Batang Toru, a collaboration between Conservation International Indonesia and the World Agroforestry Center from 2005 to 2007.

Contact: endri.martini@gmail.com

Andree Ekadinata is a remote sensing specialist who primarily focuses on image processing and spatial analysis for natural resource management, including biodiversity assessments. Andree joined the Centre in 2001 as a BSc student. He has extensive experience in interpreting images from areas in Southeast Asia, Africa and Latin America, as well as for broad application and research questions within natural resource management areas, such as climate-change mitigation, watershed management and spatial land-use planning.

Contact: a.ekadinata@cgiar.org 


\section{Abstract}

Batang Toru, located in the northern part of Sumatran island, is one of the few remaining areas to support populations of the Sumatran orangutan (Pongo abelii). The existence of an orangutan population of 400 in the area was documented through a population and habitat viability assessment (Singleton 2004). Recent studies estimate that the population may be 380 at the current time. Although the Batang Toru orangutan population is smaller, its threat from habitat loss is relatively low (below $2 \%$ annually). This low rate of habitat loss is the result of topographic features that limit access and traditional indigenous forest management systems that are sustainable and value healthy environments. Besides orangutan, the Batang Toru forest is also rich in other endemic plant and animal species (for example, Dipterocarpaceae species (Shorea spp., Anisoptera spp., Dipterocarpus spp.) and the Sumatran tiger). Up to the present, the gradient of land-use systems practised by local communities in Batang Toru has been compatible with conservation of the area's unique and globally important biodiversity. However, in the future, the expanding human population of Batang Toru may threaten the forest and all of its components if suitable livelihoods are not identified and developed. In that context, we see a number of non-timber forest products (NTFPs) that are produced in Batang Toru forest systems (for example, mixed tree gardens, agroforests and forests) as having the potential to diversify and secure viable livelihood options for the people of Batang Toru.

\section{Keywords}

Sumatran orangutan, Batang Toru, NTFPs, livelihoods, agroforest, land use 


\section{Acknowledgements}

The development of the collaborative project on orangutan habitat protection in Batang Toru watershed, North Sumatra, was funded through the United States Agency for International Development. The project was implemented by Conservation International Indonesia Program, World Agroforestry Centre (ICRAF) and Winrock International. Additionally, Winrock facilitated technical assistance to address farmers' expressed needs through the USAID-funded John Ogonowski Farmer-to-Farmer Program. Comments by Melissa Abdo, Jesus Fernandez, Sonya Dewi and Subekti Rahayu on earlier drafts improved the manuscript. 


\section{Contents}

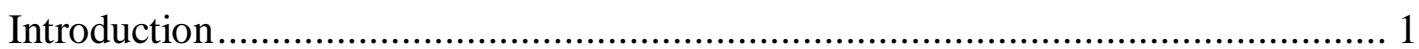

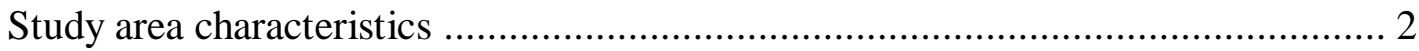

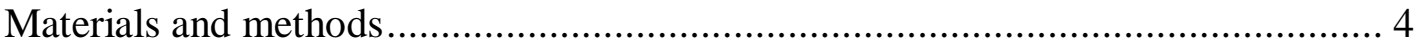

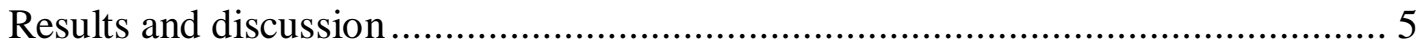

Land-cover configuration in Batang Toru ......................................................... 5

Land-cover dynamics and trajectories in Batang Toru....................................... 7

Conservation and livelihoods strategy...................................................... 7

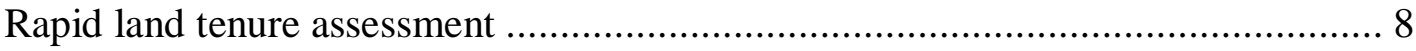

Smallholder, tree-based, farming systems ….............................................. 9

Improvement of local marketing systems .................................................. 11

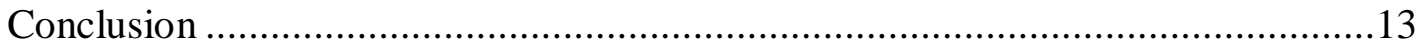

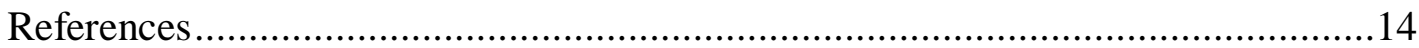




\section{Introduction}

A re-emerging paradigm in forestry studies regards 'forest' as a multi-purpose, multi-benefit resource system that should be managed to enhance the welfare of multi-stakeholders in local communities. This paradigm contends that non-timber forest products (NTFPs) have a high comparative advantage to address the needs of local communities both for household consumption and market sale to enhance family incomes. NTFPs provide a substantial proportion of income to rural households, particularly to meet seasonal needs. However, there is a shortage of information available regarding the sustainable management of these resources and the marketing of their products. Further, there are few proven means of effective information dissemination regarding sustainable management and product management.

Batang Toru, located in the northern part of Sumatran island, Indonesia, is one of the few remaining areas supporting a population of the Sumatran orangutan (Pongo abelii). The area is surrounded by roads, which separate it from the East Sarulla orangutan habitat. The Batang Toru area covers approximately 105000 ha, with an elevation of 200-1500 MASL, and is dominated by primary rainforest (MenHut 2006). The Batang Toru orangutan population was documented at 400 individuals through a population and habitat viability assessment (Singleton 2004), but more recent studies indicate the population may have decreased to about 380. Although the Batang Toru orangutan population is smaller, its threat from habitat loss is relatively low (below $2 \%$ habitat loss annually). This low rate of habitat loss could be attributed to topographic features of Batang Toru which limit access and the existing indigenous forest management systems that are sustainable and value healthy environments.

Besides orangutan, the Batang Toru forest is also rich with other endemic plant and animal species such as Dipterocarpaceae species (Shorea spp., Anisoptera spp., Dipterocarpus spp.) and the Sumatran tiger and tapir. The present gradient of land-use systems practised by local communities in Batang Toru is compatible with conservation of the area's unique and globally important biodiversity. However, the expanding human population of Batang Toru may threaten the forest and all of its components in the future if suitable livelihoods are not identified and developed. In this context, the number of NTFPs produced from Batang Toru forest systems (for example, mixed tree gardens, agroforests and forests) has the potential to diversify and secure viable livelihood options for the people of Batang Toru. The production of these NTFPs can be managed in a way that protects environmental resources.

Most smallholder, tree-based farming systems are proven to be compatible with the conservation of soil, water and biodiversity (Manurung et al. 2008). The rubber agroforestry systems (also called 'old jungle rubber') of Muara Bungo, Jambi, are analogous to smallholder systems in Batang Toru. The Muara Bungo systems contain a total of 129 woody species per hectare compared to 148 woody species per hectare identified in adjacent natural forests (Rasnovi 2006).

Many NTFP collectors and producers in the Batang Toru area are in a weak bargaining position with buyers: they are 'price takers'. The results of a rapid market assessment indicate that the current NTFP market system is of limited benefit to both producers and consumers (Kurniawan 2006). NFTP collectors are highly dependent on cash loans from traders, preserving traders dominance in NTFP market chains. In Batang Toru area, the sale of NTFPs 
does not provide a large share of total household incomes, but the income from NTFPs often fills seasonal income needs or other cashflow gaps and helps cover particular expenses including unexpected cash needs. This is why we assisted local communities to document the under-appreciated livelihood benefits NTFPs provide.

A process of facilitating local communities to conceptualise conservation and livelihoods enhancement strategies for the protection of orangutan habitat in Batang Toru area was implemented over a 1.5 year period through a project funded by the United States Agency for International Development, called 'Collaborative orangutan habitat protection in Batang Toru watershed, North Sumatra'. This was implemented by Conservation International Indonesia Program, World Agroforestry Centre and Winrock International. The Centre and Winrock worked with local communities and local government agencies to develop conservation and livelihood strategies that provided frameworks for: i) recognising communities' traditional role in conserving natural resources; ii) recognising which local agricultural and/or forest livelihood systems are compatible with environmental conservation; and iii) strengthening communities and/or other stakeholders understanding of, and commitment to, conservation as an approach to protect environmental services (biodiversity, watersheds and carbon stocks). Strategies were also deployed to identify and provide technical and marketing services and improvements that would enable communities to enhance the productivity and profitability of NTFPs in their agroforestry systems.

This paper shares insights and lessons learned on farmers' involvement in protecting and enhancing their local agroforestry livelihood systems through the Centre's experiences in developing tree nursery facilities and conservation and livelihood strategies in three districts in Batang Toru.

\section{Study area characteristics}

The study area (Figure 1) was located in the province of North Sumatra, Indonesia, covering 91400 ha. Within the area, there were a total of 251 villages located in parts of three different districts (kabupaten): North Tapanuli, Central Tapanuli and South Tapanuli. The study recorded 133971 people, constituting a total of 27906 households. The three districts had large, rural-based populations with densities varying from 126 persons per $\mathrm{km}^{2}$ in Central Tapanuli through 69 persons per $\mathrm{km}^{2}$ in North Tapanuli to 54 persons per $\mathrm{km}^{2}$ in South Tapanuli. The population was dominated by the indigenous Batak Toba, Batak Pesisir and Batak Angkola-Mandailang ethnic groups with some transmigrant communities primarily of Javanese origin. Natural forests and agroforests were the primary land cover.

The local communities in all three districts, and specifically in the study area, had a long history of sustainable forest resource management through a gradient of land-use intensities ranging through mixed tree gardens, agroforests and forests. In mixed tree gardens, the species composition was largely controlled by farmers and management was at an intermediate level of intensity. In natural forests, impact from human intervention was light with small quantities of products harvested. Agroforests (forest farming systems) were characterised by human management favouring plant species that provided useful and valuable products but management remained extensive rather than intensive. 


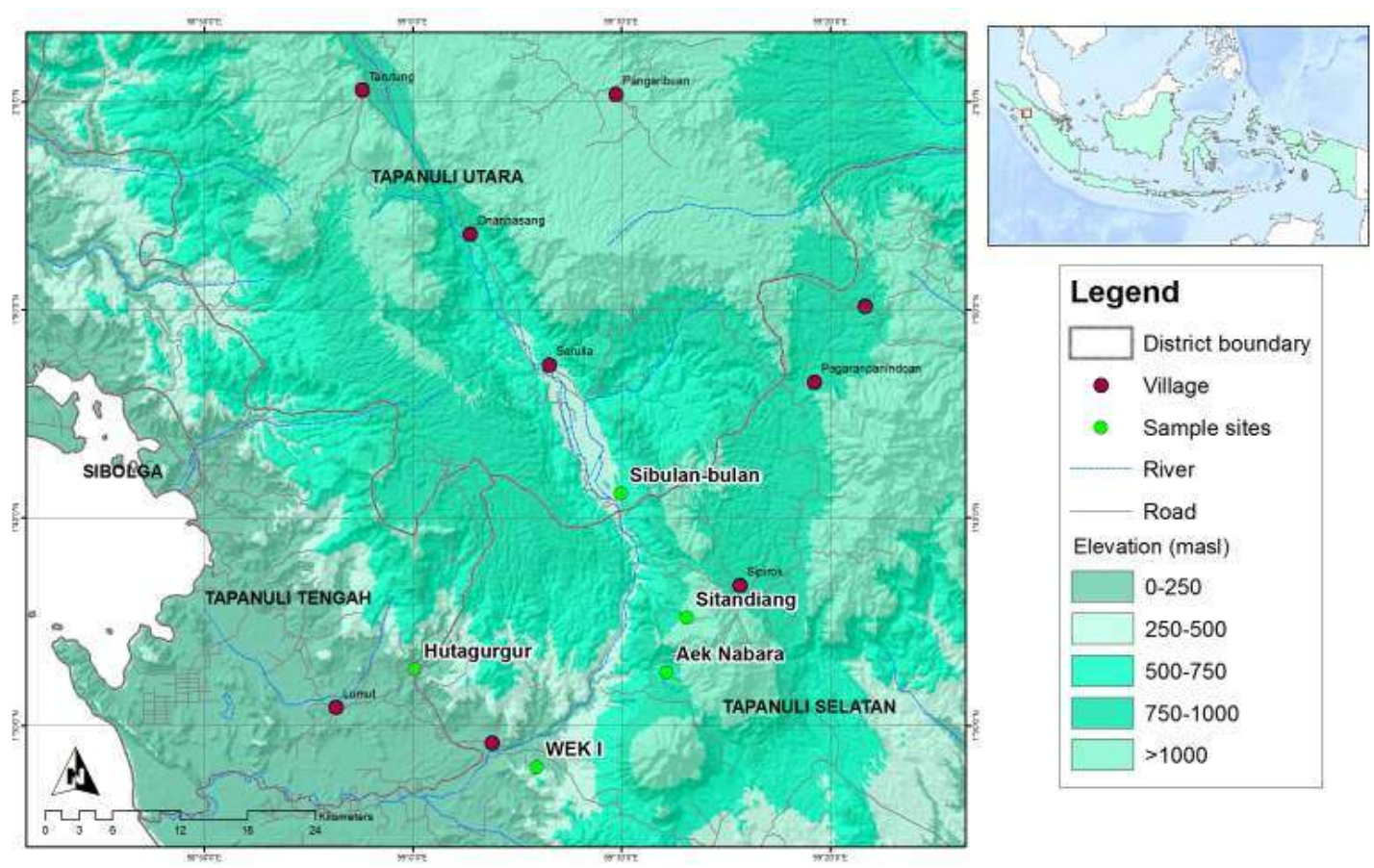

Figure 1. Coverage of study area and sample sites in Batang Toru, North Sumatra

The primary products from the mixed tree gardens of Batang Toru were rubber (Hevea brasiliensis), cacao (Theobroma cacao) and, in some villages, sugar palm (Arenga pinnata). These crops were the main source of on-farm family livelihoods, either for subsistence and/or through market sales. In the natural forests and agroforests, native species that were important or held potential include gaharu (incense from Aquillaria sp.), benzoin (Styrax benzoin), durian (Durio zibethinus), petai (Parkia speciosa), nilam (patchouli oil), aren (Arenga pinnata) and flowers (orchids and Nepenthes). Those species could be considered domesticated or semi-domesticated. The products from such species were used for home consumption and sold in local or provincial markets.

Proper planning and management of the three, tree-based, land-use systems were inadequately practised by the local communities. Observations indicated that improved management of species, crops and market linkages could enhance systems' productivity, profitability and sustainability. The predominant agricultural system in the districts was wetland rice production, which received most of the farmers' labour and other inputs. Tree-based systems received minimal management and input. 


\section{Materials and methods}

The project conducted a preliminary field survey of the study sites in October 2005. The survey was designed to obtain detailed information about agroforestry system, socioeconomic conditions, livelihood activities, market systems and orangutan habitat. The NTFPs income data was collected from key informants in each village. Information on the cash income was calculated in rupiah per month. Additional macroeconomic data was obtained from district governments. Data from the preliminary survey was used to select the key villages for the livelihoods and conservation strategy documentation (Martini et al. 2008).

To further understand the land-cover configuration and its dynamics in the Batang Toru area, we conducted a land-cover-change analysis using 1990-2000-2005 time-series, satellite images. Two types of land-cover-change analysis were conducted: 1) area-based change; and 2) trajectories. An area-based change is a simple analysis conducted by comparing total area of each land-use and land-cover class in each time period. Trajectories analysis is conducted to quantify and summarise the sequences of changes over a period of observation. 


\section{Results and discussion}

\section{Land-cover configuration in Batang Toru}

Time-series, land-cover maps of Batang Toru in 1990, 2000 and 2005 are shown in Figure 2. The accuracy of the 2005 map is $85 \%$. The maps clearly show that Batang Toru areas were dominated by two land-cover types: forest and mixed tree garden. Most of the high altitude areas were still covered by forest in 2005. Mixed tree gardens dominated areas surrounding forest patches, especially in the western forest block of Batang Toru.

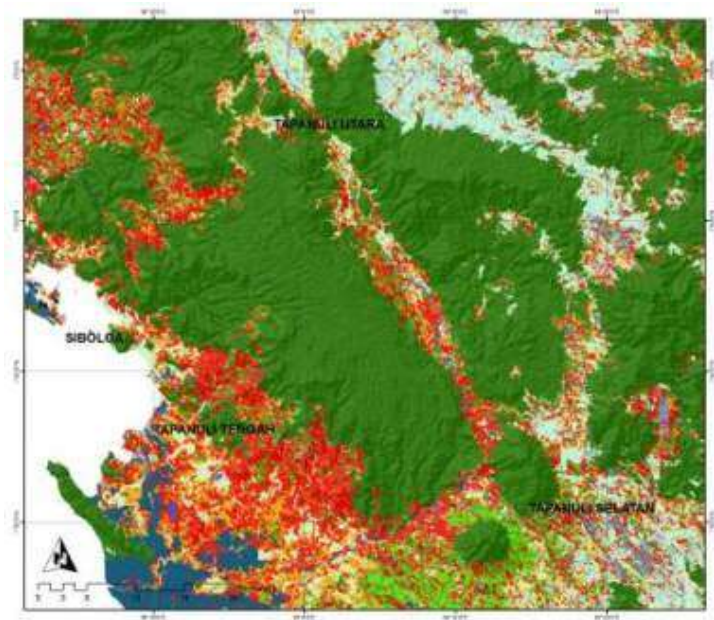

1990

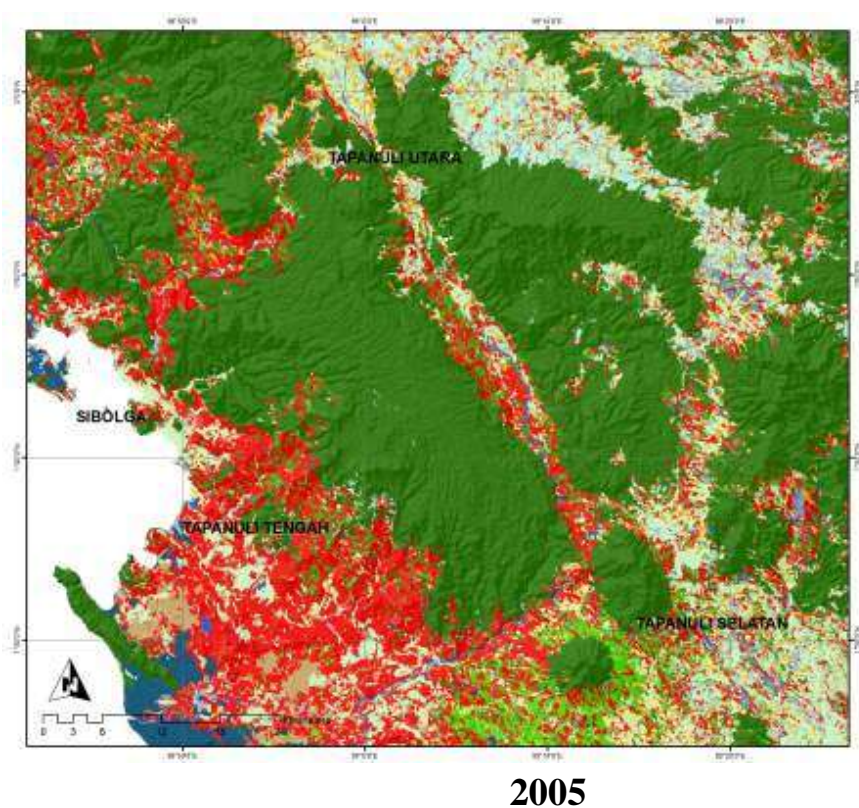

\section{5}

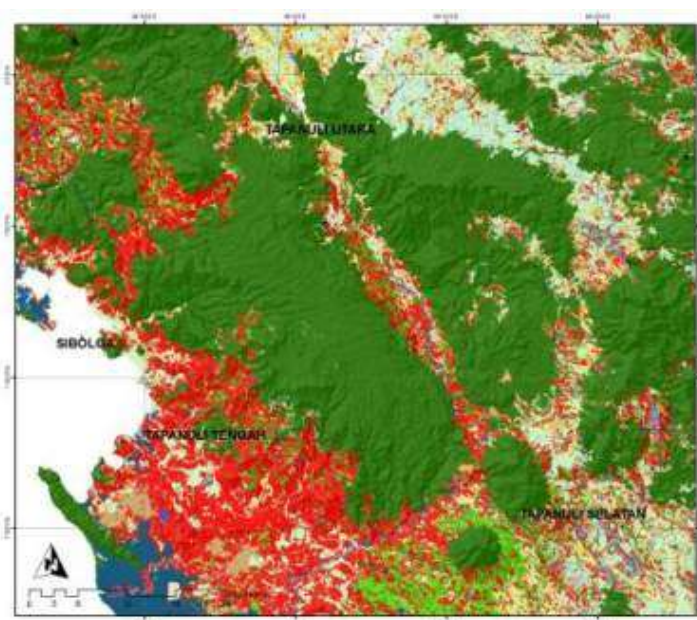

2000

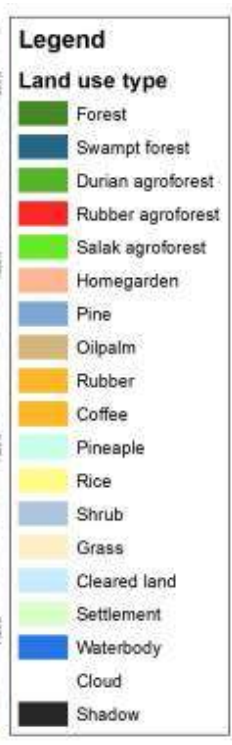

Figure 2. Time-series, land-use maps of the Batang Toru area

Several types of mixed tree gardens were identified from the satellite images: rubber agroforest, durian agroforest, salak agroforest and home garden. Rubber agroforests could be seen in fairly large and continuous patches surrounding the eastern forest block. Durian agroforests were located near forest edges in smaller concentrations, while salak agroforests were mostly located in the southern parts of the forest blocks. These patches of mixed tree gardens appeared to remain stable since the 1990-to-2005 period. 
In contrast to the western block, the eastern block of Batang Toru was dominated by agricultural land: pineapple, coffee and rice fields. Mixed tree gardens only appeared in small patches in these areas. The eastern block seemed to be more dynamic in terms of land-cover change compared to the western block. Decline in forest cover and an increasing area of agriculture were two dominant changes in this part of Batang Toru.

Monoculture plantations were mostly located in the southern part of the study area. Rubber plantations are the most dominant land-cover type in this category. Small patches of oil palm were identified in this area from the year 2000 land-cover maps, increasing in area by 2005 .

Table 1. Summary of land-cover change in Batang Toru 1990-2005

\begin{tabular}{|c|c|c|c|c|c|c|c|}
\hline \multirow{2}{*}{ No } & \multirow{2}{*}{ Class } & \multicolumn{2}{|l|}{1990} & \multicolumn{2}{|l|}{2000} & \multicolumn{2}{|l|}{2005} \\
\hline & & ha & $\%$ & ha & $\%$ & ha & $\%$ \\
\hline 1 & Forest & 336064.1 & $50 \%$ & 319478.4 & $47 \%$ & 316268 & $47 \%$ \\
\hline 2 & Swamp forest & 22459.41 & $3 \%$ & 16838.1 & $3 \%$ & 13938.3 & $2 \%$ \\
\hline 3 & $\begin{array}{l}\text { Durian } \\
\text { agroforest }\end{array}$ & 40441.5 & $6 \%$ & 36494.55 & $5 \%$ & 35642.61 & $5 \%$ \\
\hline 4 & $\begin{array}{l}\text { Rubber } \\
\text { agroforest }\end{array}$ & 98272.35 & $15 \%$ & 96304.05 & $14 \%$ & 95620.77 & $14 \%$ \\
\hline 5 & $\begin{array}{l}\text { Salak } \\
\text { agroforest }\end{array}$ & 17595.18 & $3 \%$ & 16283.61 & $2 \%$ & 15558.66 & $2 \%$ \\
\hline 6 & Rubber & 25308.54 & $4 \%$ & 30782.34 & $5 \%$ & 30123.99 & $4 \%$ \\
\hline 7 & Oil palm & & $0 \%$ & 4698.72 & $1 \%$ & 7492.32 & $1 \%$ \\
\hline 8 & Pine & 8218.26 & $1 \%$ & 6534.27 & $1 \%$ & 6267.24 & $1 \%$ \\
\hline 9 & Homegarden & 5716.8 & $1 \%$ & 3799.53 & $1 \%$ & 1992.33 & $0 \%$ \\
\hline 10 & Coffee & 10602.63 & $2 \%$ & 20047.32 & $3 \%$ & 20860.11 & $3 \%$ \\
\hline 11 & Pineapple & 35577.9 & $5 \%$ & 30936.87 & $5 \%$ & 27288.27 & $4 \%$ \\
\hline 12 & Shrub & 13145.85 & $2 \%$ & 11632.77 & $2 \%$ & 15865.2 & $2 \%$ \\
\hline 13 & Grass & 973.35 & $0 \%$ & 3068.46 & $0 \%$ & 270.09 & $0 \%$ \\
\hline 14 & Rice & 12557.07 & $2 \%$ & 15046.83 & $2 \%$ & 14233.77 & $2 \%$ \\
\hline 15 & Cleared land & 2904.84 & $0 \%$ & 164.52 & $0 \%$ & 3673.8 & $1 \%$ \\
\hline 16 & Settlement & 38223.18 & $6 \%$ & 52145.82 & $8 \%$ & 63642.24 & $9 \%$ \\
\hline 17 & Waterbody & 3931.65 & $1 \%$ & 3931.65 & $1 \%$ & 3931.65 & $1 \%$ \\
\hline \multirow[t]{2}{*}{18} & $\begin{array}{l}\text { Cloud and } \\
\text { shadow }\end{array}$ & 676.8 & $0 \%$ & 4481.55 & $1 \%$ & & $0 \%$ \\
\hline & & & & 672669.4 & & 672669.4 & \\
\hline
\end{tabular}




\section{Land-cover dynamics and trajectories in Batang Toru}

The area summary of land-cover types in Batang Toru is shown in Table 1. Three types of dominant land-cover changes can be summarised from the time-series, land-cover maps: (1) decrease of forest cover; (2) decrease of mixed tree gardens; (3) increase of monoculture plantations. Although forest was still a major land cover in Batang Toru, its area has been continuously declining from $54 \%$ in 1990 to $50 \%$ in 2005 . The sharpest decline of forest cover occurred during 1990-2000, decreasing from 336064.1 ha in 1990 to 319478.4 ha in 2000.

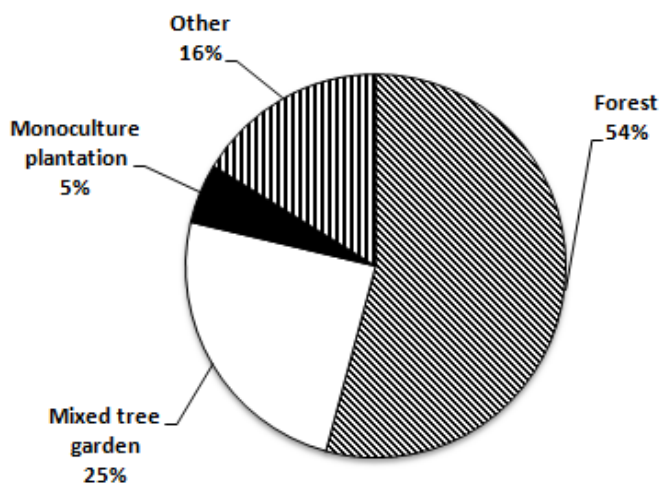

1990

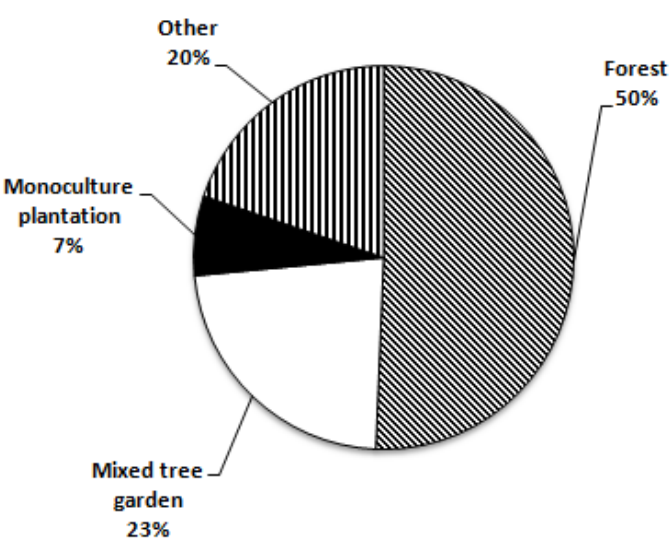

2005

Figure 3. Major land-cover changes in Batang Toru

\section{Conservation and livelihoods strategy}

Centre and Winrock staff stationed at the site, with support from other specialists, were responsible for developing conservation and livelihoods strategies for key Batang Toru villages. Four conservation concepts served as the basis for the formulation of the strategies.

1. Recognition of communities' traditional role in conserving natural resources.

2. Recognition of local agricultural and forest livelihoods systems that are compatible with environmental conservation.

3. Strengthening of communities' and stakeholders' understanding and commitment to conservation as an approach to sustain environmental services (biodiversity, watersheds and carbon stocks).

4. Identification of technical assistance on management and marketing that would enable communities to enhance the productivity and profitability of NTFPs in their agroforestry systems.

Raising awareness amongst stakeholders was an important first step towards developing livelihoods and conservation strategies. Local communities were considered the main beneficiaries of the strategies. To help strengthen their understanding of the concept of a livelihoods and conservation strategy, the project developed and implemented integrated training. 


\section{Rapid land tenure assessment}

The project used the rapid land tenure assessment (RATA) method developed by the Centre to identify the local community's traditional role in conserving natural resources. RATA is a method that documents historic land tenure, land use, related issues and policy options to resolve conflicts (Galudra et al. 2006).

Some government agencies with support from international and local NGOs proposed the Batang Toru watershed as a national park for the purpose of conserving and protecting the habitat of orangutan (Perbatakusuma 2006). In the proposal, the urgent need for a national park in the area was justified owing to the threat of deforestation. As of 2008, the North Sumatra Province had lost about 71000 ha of its forests. It was assumed that the Batang Toru watershed had experienced, or was threatened by, a similar loss of forest and habitat that would threaten the local orangutan population (Wich et al. 2003). However, site specific research in and surrounding Batang Toru shows that local communities help protect the forest and conservation areas if their traditional land tenure is recognised. This finding supports a dynamic policy option on the best way to conserve and protect the orangutan habitat, that is, through rewarding those people who demonstrate and respect the local practice of effective conservation.

Recognition of traditional tenure claims would be more effective than approving a proposal to establish a national park, which was developed with limited transparency, and limited involvement of local communities or prioritisation of communities' priorities and needs. Additionally, the legal status of land in the Batang Toru area remains uncertain.

Since 1936, only half of the Batang Toru watershed has been gazetted as state forest land (Figure 4). Although the government claims the area as state forest land through Minister Decree No. 44/2006, local communities also have valid tenure claims under adat or customary law. Batang Toru populations qualify as traditional communities who still practise their culture. Around 32573 ha of the state forest land has been used by local communities since the 1930s and is acknowledged as agroforest garden. Over half of this area (17 $392 \mathrm{ha}$ ) is under customary land-use rights legally recognised by the National Land Agency. However, forestry authorities refused to recognise either the communities' customary rights or acknowledge the National Land Agency's jurisdiction. 


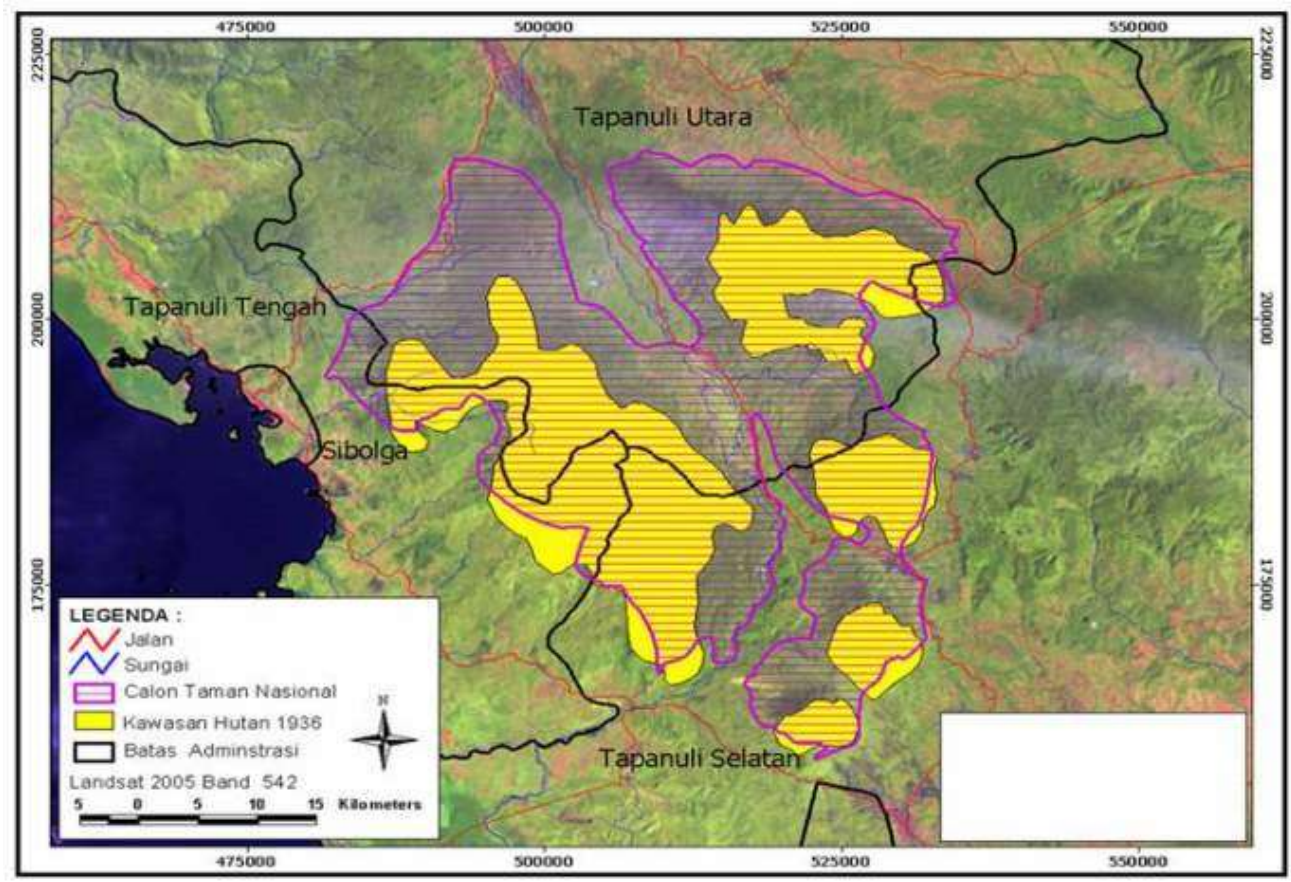

Figure 4. Delineation of forest status in 1936 (overlapping with Landsat image 2005)

Current efforts to enhance orangutan conservation in the area need to consider the perspectives of the local stakeholders who are the de facto managers and protectors of the Batang Toru forested area. By ignoring valid local claims, particularly from communities who respect conservation, forestry authorities risk an escalation of tension and possible conflict that may make non-participatory, non-transparent conservation efforts counter-productive (Roshetko et al. 2007b).

\section{Smallholder, tree-based, farming systems}

In Batang Toru, NTFP products were correlated with smallholder, tree-based, farming systems (agroforestry) and forest itself. Agroforestry is a collective name for land-use systems and practices in which woody perennials are deliberately integrated with crops and/or animals in the same land management unit. The integration can be either in a spatial mixture or in a temporal sequence. There are normally both ecological and economic interactions between woody and non-woody components in agroforestry. These tree-based farming systems practised at the study sites were usually characterised by limited proactive management and planning. They were managed on a traditionally extractive basis with few inputs (quality germplasm, fertilisers, labour etc). Spacing is irregular and species components were often primarily the result of chance. Harvesting products was often the most common management activity, with minimal weeding to control herbaceous and woody competition (Manurung et al. 2008). As a result, the quality and quantity of products was far below the systems' potential. Farmers often occupied weak positions and were ill prepared to assume an active marketing role. Farmers generally: i) lacked access to market information (product demand, specifications and prices); ii) lacked understanding of market channels; iii) produced products of unreliable quality and quantity; and iv) rarely engaged in grading or processing to improve product quality (and their profit-margin) (Roshetko et al. 2007a). 
Farmers were usually interested in intensifying the management of their tree-based farming systems, but hesitated because they did not know where and how to focus their efforts (Roshetko et al. 2007a). Resource scarcity, absence of knowledge regarding propagation and management, limited access to market and governments' policy disincentives and ambiguities were the limiting factors for farmers to intensify the management of their tree-farming systems (Gintings et al. 1996). Under conditions of insecure land tenure and market access, smallholder farmers cannot and will not cultivate a wide range of tree species as a component of their efficient, integrated and risk-averse livelihood and land-use systems and will not effectively respond to the increased demand for wood products (van Noordwijk et al. 2003).

Developing a replicable and efficient extension approach designed to reach motivated and innovative farmers can mobilise the strength of community-based forest management. These farmers are those who are committed to improving their incomes and environmental services by increasing the production and market access for their agroforestry products (Roshetko et al. 2007a). The extension approach requires the provision of a series of workshop training sessions to farmer leaders and more intensive follow-up assistance to farmer groups - that the leaders have helped to organise - focussing on agroforest productivity enhancement and marketing. Listed below are the NTFPs derived from agroforestry systems in Batang Toru.

Table 2. Types of NTFPs in Batang Toru

\begin{tabular}{|c|c|c|c|c|}
\hline \multirow[b]{2}{*}{ No. } & \multirow[b]{2}{*}{ Plant species } & \multicolumn{2}{|c|}{ Use } & \multirow[b]{2}{*}{ Remarks } \\
\hline & & $\begin{array}{l}\text { Marketable } \\
\text { products }\end{array}$ & Subsistence & \\
\hline 1 & $\begin{array}{l}\text { Arenga pinnata } \\
\text { (aren) }\end{array}$ & $\begin{array}{l}\text { Brown sugar, } \\
\text { Thatch, } \\
\text { Kolang kaling }\end{array}$ & $\begin{array}{l}\text { Tuak (alcoholic } \\
\text { beverage) }\end{array}$ & $\begin{array}{l}\text { Farmers produce brown sugar and sell } \\
\text { direct in local markets }\end{array}$ \\
\hline 2 & $\begin{array}{l}\text { Hevea brasiliensis } \\
\text { (rubber) }\end{array}$ & Latex & Fuel wood & $\begin{array}{l}\text { Farmers produce rubber and sell weekly in } \\
\text { local markets }\end{array}$ \\
\hline 3 & $\begin{array}{l}\text { Coffea robusta } \\
\text { (coffee) }\end{array}$ & Fruit & Fuel wood & $\begin{array}{l}\text { Farmers produce coffee and sell direct in } \\
\text { local markets }\end{array}$ \\
\hline 4 & $\begin{array}{l}\text { Durio zibethinus } \\
\text { (durian) }\end{array}$ & Fruit & Wood & $\begin{array}{l}\text { Farmers produce durian in mixed gardens, } \\
\text { agroforests and forests for sale in local } \\
\text { markets }\end{array}$ \\
\hline 5 & $\begin{array}{l}\text { Parkia speciosa } \\
\text { (petal) }\end{array}$ & Fruit & Fruit & $\begin{array}{l}\text { Farmers produce petai in mixed forests, } \\
\text { agroforests and forests for sale in local } \\
\text { markets }\end{array}$ \\
\hline 6 & $\begin{array}{l}\text { Styrax benzoin } \\
\text { (benzoin) }\end{array}$ & Resin & Fuel wood & $\begin{array}{l}\text { Production was low owing to low market } \\
\text { demand and price }\end{array}$ \\
\hline 7 & $\begin{array}{l}\text { Cinnamomum } \\
\text { burmanii } \\
\text { (cinnamon) } \\
\end{array}$ & Bark & Fuel wood & $\begin{array}{l}\text { Farmers produce cinnamon and sell in local } \\
\text { markets }\end{array}$ \\
\hline 8 & $\begin{array}{l}\text { Lansium } \\
\text { domesticum (duku) }\end{array}$ & Fruit & Fruit & $\begin{array}{l}\text { Farmers produce duku and sell in local } \\
\text { markets }\end{array}$ \\
\hline
\end{tabular}




\section{Box 1: Carbon storage in mixed tree gardens of Batang Toru}

\section{Subekti Rahayu and Andree Ekadinata}

As non-forest land-use systems, sustainable mixed tree gardens in Batang Toru have the potential to store carbon for a long period. Studies on carbon stock for every land-use system in Batang Toru concluded that the carbon stock of forest in Batang Toru was 243 tonne per hectare while the carbon stock in mixed tree gardens, such as durian and salak agroforests, ranged through 90-100 tonne of carbon per hectare.

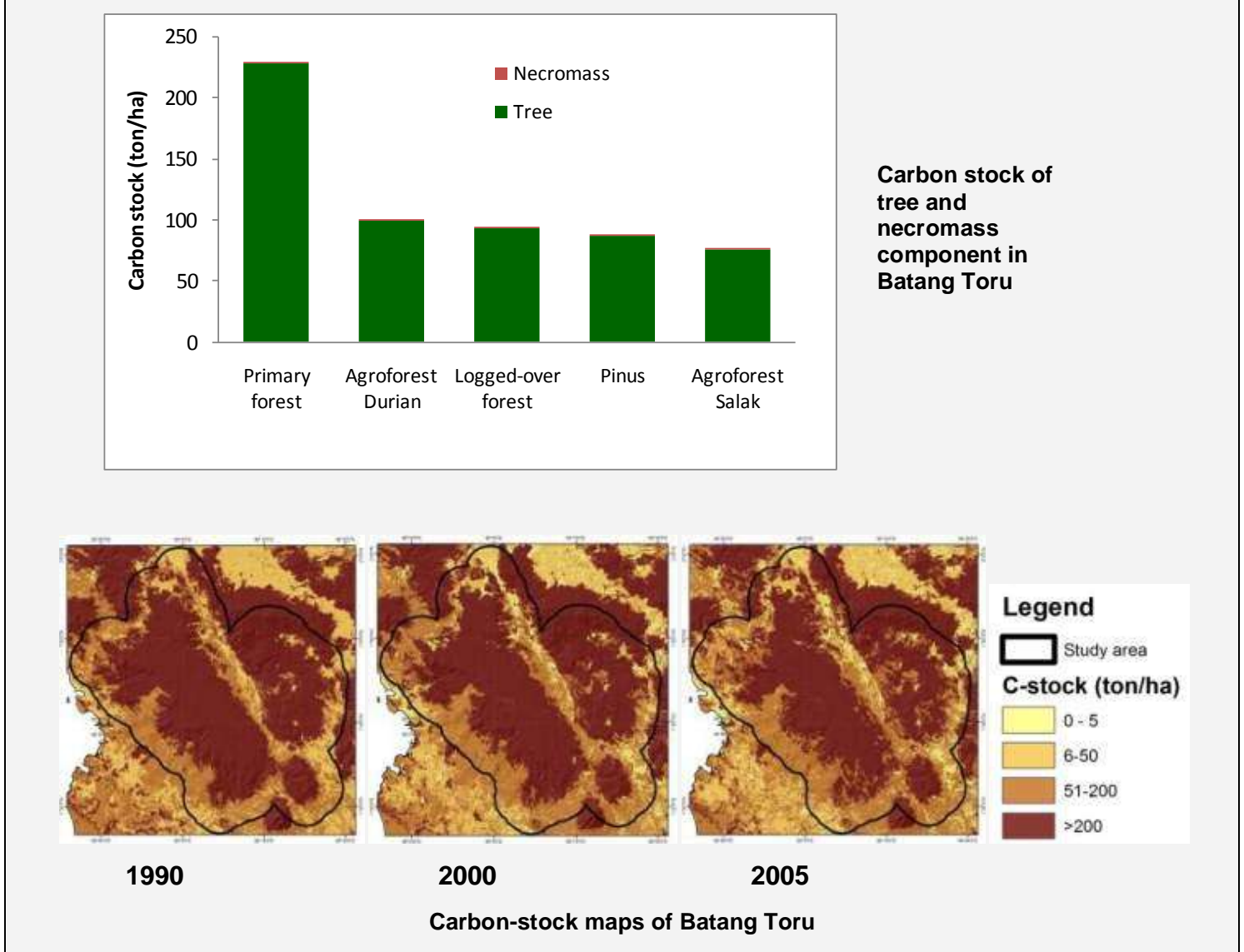

\section{Improvement of local marketing systems}

Cash from sale of NTFPs can represent an important contribution to farmers' income. Effective and suitable marketing can help farmers optimise income from those products and maintain income stability. Effective marketing strategies can also reduce the risk of market over-supply, which drives down product prices. Batang Toru watershed provided many valuable NTFPs. Some of the NTFP products had economic value but were traded in small, irregular quantities with low prices received by the farmer producer or collector.

In Indonesia, most smallholder farmers have poor market knowledge and links (Roshetko and Yulianti 2002). In Batang Toru this is illustrated in the case of palm sugar. Project surveys and interviews with farmers documented that the demand for palm sugar exceeded supply, indicating palm sugar held great potential for communities with established palm gardens. However, owing to poor market intelligence farmers' products did not match market specifications. The market prefered small-sized units (500-1000 gram) of palm sugar, 
however, farmers processed palm sugar in larger-sized units (>10 kg). Colour and packaging also influenced traders' preferences and prices for palm sugar but, again, most farmers did not consider those factors when processing their palm sugar.

Amongst key NTFPs available in the Batang Toru area (Figure 5), rubber made the biggest contribution to household incomes (40\%) followed by durian (18\%) and coffee (17\%). Other crops providing additional income to the household were cacao (Theobroma cacao) (9\%) and betel nut (Areca catechu) (7\%). All five of those products were mainly harvested from treebased gardens or agroforests.
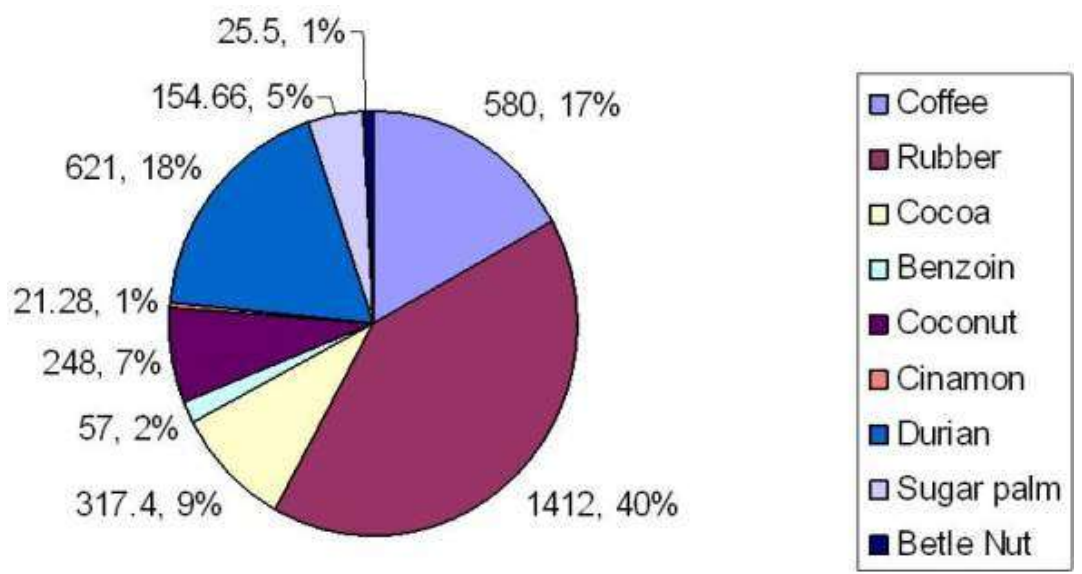

Figure 5. Average income percentage from NTFPs in households surrounding the Batang Toru watershed forest block.

Smallholder farmers in Indonesia have marketing constraints mainly related to a lack of market information regarding market demand and specification, price fluctuations, product quantity and quality and market channels (Roshetko and Yulianti 2002). These constraints can be drastically reduced if farmers can access accurate market information to create marketing strategies. A good market information system identifes farmer-producers' opportunities and information on technology availability to support NTFP production that meets market demands and specifications. Linking NFTP production with market information can help farmers improve their natural resource management to generate greater income. 


\section{Conclusion}

As a process, the development of NTFP strategy activities was dynamic and developed based on community needs and environmental conditions. Based on our observations and experiences, the successful development of NTFP strategies required communication between the community, local governments and other relevant stakeholders by considering four issues.

1. Recognition of communities traditional role in conserving natural resources.

2. Recognition of local agricultural and forest livelihood systems that were compatible with environmental conservation.

3. Strengthen communities and stakeholders understanding of, and commitment to, conservation as an approach to sustain environmental services (biodiversity, watersheds and carbon stocks).

4. Identification of technical assistance on management and marketing that enabled communities to enhance the productivity and profitability of NTFPs in their agroforestry systems.

The NTFP strategies that were developed by the Centre in collaboration with Winrock International put more emphasis on local capacity building as an approach to improve technical and marketing skills and at the same time enhance understanding of the importance developing livelihoods and conservation strategies, particularly at the village level. The main purposes of the approach were i) to improve the productivity and profitability of smallholder agroforest systems; and ii) to draw attention to Batang Toru farmers' long and successful history of forest conservation, making possible recognition and reward for the valuable environmental services the communities provide. Although new, these efforts were acknowledged as useful by local stakeholders, particularly farmers. Improved awareness by local people regarding the use of better rubber germplasm and improved management of their agroforests garden could integrate livelihoods with conservation issues. 


\section{References and further reading}

Galudra G, Pasya G, Sirait MT, Fay CC. 2006. Rapid Land Tenure Assessment (RaTA): panduan ringkas bagi praktisi (A quick guide for practitioners). Bogor, Indonesia: World Agroforestry Centre (ICRAF) Southeast Asia Regional Program.

Gintings AN, Anwar C, Samsudin I, Siregar ME, Punama BM, Kasirin. 1996. Agroforestry characterization in Pakuan Ratu and Tulang Bawang Tengah, North Lampung District, Lampung. In: van Noordwijk M, Tomich T, Garrity D, Fagi A, eds. Proceedings of a workshop: Alternatives to Slash-and-Burn Research in Indonesia. Bogor, Indonesia, 69 June 1995. ASB Indonesia Report 6. Bogor, Indonesia: ASB Indonesia; World Agroforestry Centre (ICRAF) Southeast Asia Regional Program. p. 59-68.

Kurniawan I. 2006. Trip report on preliminary visit finding of marketing study from Nanggung and Batang Toru projects. Bogor, Indonesia: World Agroforestry Centre (ICRAF) Southeast Asia Regional Program.

Kuswanda W. 2006. Status terkini populasi dan ancaman fragmentasi habitat orangutan (Pongo abelii) di kawasan hutan Batang Toru: studi kasus Cagar Alam Dolok Sibualibuali. Paper presented at workshop 'Masa depan habitat orangutan dan pembangunan di kawasan hutan daerah aliran sungai Batang Toru', Central Tapanuli, North Sumatra, Indonesia, 17-18 January 2006.

Manurung GE, Roshetko JM, Budidarsono S, Kurniawan I. 2008. Dudukuhan tree farming systems in West Java: how to mobilize self-strengthening of community-based forest management? In: Snelder DJ, Lasco RD, eds. Smallholder tree-growing for rural development and environmental services. Advances in agroforestry: lessons from Asia. Vol. 5. New York: Springer.

Martini E, Tarigan J, Roshetko J, Manurung G, Kurniawan I, Tukan J, Budidarsono S, Abdo M, van Noordwijk M. 2008. Capacity building activities to strengthen agroforestry as sustainable economic alternative in the orangutan habitat conservation program of Batang Toru, North Sumatra. Working Paper 61. Bogor, Indonesia: World Agroforestry Centre (ICRAF) Southeast Asia Program.

Perbatakusuma EA, Wurjanto D, Sihombing L. 2007. Proposal Strategi Konservasi Orangutan Sumatera (Pongo abelii) di daerah aliran sungai Batang Toru Provinsi Sumatera Utara (Conservation strategy proposal for Sumatran orangutan (Pongo abelii) in Batang Toru Watershed, North Sumatra). Paper presented in workshop 'Building a collaboration of the parties to the Sumatran orangutan habitat conservation strategy and sustainable community economic development in Batang Toru Watershed', 28-30 March 2007, Medan, North Sumatra, Indonesia.

Rasnovi S. 2006. Ekologi regenerasi tumbuhan berkayu pada sistem agroforest karet (Regeneration ecology of woody plants in rubber agroforestry systems). Bogor, Indonesia: World Agroforestry Centre (ICRAF) Southeast Asia Program.

Roshetko JM, Yulianti. 2002. Pemasaran untuk hasil-hasil wanatani di tingkat petani (Marketing of agroforestry products at farmer level). In: Roshetko JM, Mulawarman, Santoso WJ, Oka IN. Wanatani di Nusa Tenggara (Agroforestry in Nusa Tenggara). Proceedings of workshop 'Wanatani Se-Nusa Tenggara', 11-14 November 2001, 
Denpasar, Bali, Indonesia. Bogor, Indonesia: World Agroforestry Centre (ICRAF) Southeast Asia Program; Winrock International.

Roshetko JM, Nugraha E, Tukan JCM, Manurung G, Fay C, van Noordwijk M. 2007a. Agroforestry for livelihood enhancement and enterprise development. In: Djoeroemana S, Myers B, Russell-Smith J, Blyth M, Salean IET, eds. Integrated rural development in East Nusa Tenggara, Indonesia. Proceedings of workshop 'Identify sustainable rural livelihoods', Kupang, Indonesia, 5-7 April 2006. ACIAR Proceedings 126. Canberra: Australian Centre for International Agricultural Research.

Roshetko JM, Martini E, Tarigan J, Manurung G, Budidarsono S, Wijaya K, Tukan JC, Kurniawan I, Galudra G, Nugroho DK, Ekadinata A, Dewi S, Harja D, Lusiana B, van Noordwijk M, Purba J. 2007b. Agroforestry on the interface of orangutan conservation and sustainable livelihoods in Batang Toru (North Sumatra). Working Paper 56. Bogor, Indonesia: World Agroforestry Centre (ICRAF) Southeast Asia Regional Program.

Tarigan J, Martini E, Roshetko J and Kurniawan I. 2008. A documentation strategy to develop the potential of NTFPs as a source of livelihood diversification for local communities in the Batang Toru orangutan conservation program. In: International Union for the Conservation of Nature and Natural Resources. The role of NTFPs in poverty alleviation and biodiversity. Conference proceedings. Hanoi: International Union for Conservation of Nature and Natural Resources.

Tukan J. 2006. Summary report of Batang Toru marketing training, 25-27 May 2006. Bogor, Indonesia: World Agroforestry Centre (ICRAF), Southeast Asia Regional Program.

Singleton I. 2004. Orangutan di Sumatera: DAS Batang Toru (Orangutan in Sumatra: Batang Toru watershed). Workshop paper at 'Masa depan habitat orangutan dan pembangunan di kawasan hutan daerah aliran sungai Batang Toru' (Future orangutan habitat development in the Batang Toru forest watershed), 17-18 January 2006, Sibolga, Indonesia.

Wich SA, Singleton I, Utami-Atmoko SS, Geurts ML, Rijksen HD, van Schaik CP. 2003. The status of the Sumatran orang-utan Pongo abelii: an update. Oryx 37(1). p. 49-54. DOI 10.1017/S0030605303000115.

Van Noordwijk M, Roshetko JM, Murniati, de los Angeles M, Suyanto, Fay CC, Tomich TP. 2003. Agroforestry is a form of sustainable forest management: lessons from South East Asia. Working Paper 2003 2. Bogor, Indonesia: World Agroforestry Centre (ICRAF) Southeast Asia Program.

Van Noordwijk M. 2006. Orangutans, farmers and alternatives to a national park: report of visit to ICRAF activities in the Batang Toru area, 28 July-2 August 2006. Bogor, Indonesia: World Agroforestry Centre (ICRAF) Southeast Asia Program. 


\section{Working papers in this series}

2005

1. Agroforestry in the drylands of eastern Africa: a call to action.

2. Biodiversity conservation through agroforestry: managing tree species diversity within a network of community-based, nongovernmental, governmental and research organizations in western Kenya.

3. Invasion of prosopis juliflora and local livelihoods: case study from the Lake Baringo area of Kenya.

4. Leadership for change in farmers organizations: training report: Ridar Hotel, Kampala, 29th March to 2nd April 2005.

5. Domestication des espèces agroforestières au Sahel: situation actuelle et perspectives.

6. Relevé des données de biodiversité ligneuse: manuel du projet biodiversité des parcs agroforestiers au Sahel.

7. Improved land management in the Lake Victoria Basin: TransVic Project's draft report.

8. Livelihood capital, strategies and outcomes in the Taita hills of Kenya.

9. Les espèces ligneuses et leurs usages: les préférences des paysans dans le Cercle de Ségou, au Mali.

10. La biodiversité des espèces ligneuses: Diversité arborée et unités de gestion du terroir dans le Cercle de Ségou, au Mali.

2006

11. Bird diversity and land use on the slopes of Mt Kilimanjaro and the adjacent plains, Tanzania.

12. Water, women and local social organization in the Western Kenya Highlands.

13. Highlights of ongoing research of the World Agroforestry Centre in Indonesia.

14. Prospects of adoption of tree-based systems in a rural landscape and its likely impacts on carbon stocks and farmers' welfare: The FALLOW Model Application in Muara Sungkai, Lampung, Sumatra, in a 'Clean Development Mechanism' context.

15. Equipping integrated natural resource managers for healthy agroforestry landscapes.

16. Are they competing or compensating on farm? Status of indigenous and exotic tree species in a wide range of agro-ecological zones of Eastern and Central Kenya, surrounding Mt Kenya.

17. Agro-biodiversity and CGIAR tree and forest science: approaches and examples from Sumatra.

18. Improving land management in eastern and southern Africa: a review of policies.

19. Farm and household economic study of Kecamatan Nanggung, Kabupaten Bogor, Indonesia: a socio-economic baseline study of agroforestry innovations and livelihood enhancement.

20. Lessons from eastern Africa's unsustainable charcoal business.

21. Evolution of RELMA's approaches to land management: lessons from two decades of research and development in eastern and southern Africa. 
22. Participatory watershed management: Lessons from RELMA's work with farmers in eastern Africa.

23. Strengthening farmers' organizations: the experience of RELMA and ULAMP.

24. Promoting rainwater harvesting in eastern and southern Africa.

25. The role of livestock in integrated land management.

26. Status of carbon sequestration projects in Africa: potential benefits and challenges to scaling up.

27. Social and environmental trade-offs in tree species selection: a methodology for identifying niche incompatibilities in agroforestry [appears as AHI Working Paper 9].

28. Managing tradeoffs in agroforestry: from conflict to collaboration in natural resource management [appears as AHI Working Paper 10].

29. Essai d'analyse de la prise en compte des systemes agroforestiers pa les legislations forestieres au Sahel: cas du Burkina Faso, du Mali, du Niger et du Senegal.

30. Etat de la recherche agroforestière au Rwanda etude bibliographique, période 19872003.

\section{7}

31. Science and technological innovations for improving soil fertility and management in Africa: a report for NEPAD's Science and Technology Forum.

32. Compensation and rewards for environmental services.

33. Latin American regional workshop report compensation for ecosystem services.

34 Asia regional workshop on compensation for ecosystem services.

35 African regional workshop on compensation for ecosystem services.

36 Exploring the inter-linkages among and between compensation and rewards for ecosystem services (CRES) and human well-being.

37 Criteria and indicators for environmental service compensation and reward mechanisms: realistic, voluntary, conditional and pro-poor.

38 The conditions for effective mechanisms of compensation and rewards for environmental services.

39 Organization and governance for fostering pro-poor compensation for environmental services.

40 How important are different types of compensation and reward mechanisms shaping poverty and ecosystem services across Africa, Asia and Latin America over the next two decades?

41. Risk mitigation in contract farming: the case of poultry, cotton, woodfuel and cereals in East Africa.

42. The RELMA savings and credit experiences: sowing the seed of sustainability

43. Policy and institutional context for NRM in Kenya: challenges and opportunities for Landcare.

44. Nina-Nina Adoung Nasional di So! Field test of rapid land tenure assessment (RATA) in the Batang Toru watershed, North Sumatra.

45. Is Hutan Tanaman Rakyat a new paradigm in community-based tree planting in Indonesia? 
46. Socio-economic aspects of brackish water aquaculture (tambak) production in Nanggroe Aceh Darrusalam.

47. Farmer livelihoods in the humid forest and moist savannah zones of Cameroon.

48. Domestication, genre et vulnérabilité:pParticipation des femmes, des jeunes et des catégories les plus pauvres à la domestication des arbres agroforestiers au Cameroun.

49. Land tenure and management in the districts around Mt Elgon: an assessment presented to the Mt Elgon ecosystem conservation programme.

50. The production and marketing of leaf meal from fodder shrubs in Tanga, Tanzania: a pro-poor enterprise for improving livestock productivity.

51. Buyers perspectives on environmental services (ES) and commoditization as an approach to liberate ES markets in the Philippines.

52. Towards community-driven conservation in southwest China: reconciling state and local perceptions.

53. Biofuels in China: an analysis of the opportunities and challenges of Jatropha curcas in Southwest China.

54. Jatropha curcas biodiesel production in Kenya: economics and potential value chain development for smallholder farmers

55. Livelihoods and forest resources in Aceh and Nias for a sustainable forest resource management and economic progress.

56. Agroforestry on the interface of orangutan conservation and sustainable livelihoods in Batang Toru, North Sumatra.

2008

57. Assessing hydrological situation of Kapuas Hulu Basin, Kapuas Hulu Regency, West Kalimantan.

58. Assessing the hydrological situation of Talau Watershed, Belu Regency, East Nusa Tenggara.

59. Kajian kondisi hidrologis DAS Talau, Kabupaten Belu, Nusa Tenggara Timur.

60. Kajian kondisi hidrologis DAS Kapuas Hulu, Kabupaten Kapuas Hulu, Kalimantan Barat.

61. Lessons learned from community capacity-building activities to support agroforest as sustainable economic alternatives in Batang Toru orangutan habitat conservation program.

62. Mainstreaming climate change in the Philippines.

63. A conjoint analysis of farmer preferences for community forestry contracts in the Sumber Jaya Watershed, Indonesia.

64. The Highlands: a shower water tower in a changing climate and changing Asia.

65. Eco-certification: can it deliver conservation and development in the tropics?

66. Designing ecological and biodiversity sampling strategies: towards mainstreaming climate change in grassland management.

67. Participatory poverty and livelihood assessment report, Kalahan, Nueva Vizcaya, the Philippines.

68. An assessment of the potential for carbon finance in rangelands.

69. ECA trade-offs among ecosystem services in the Lake Victoria Basin. 
70. Le business plan d'une petite entreprise rurale de production et de commercialisation des plants des arbres locaux: cas de quatre pépinières rurales au Cameroun.

71. Les unités de transformation des produits forestiers non ligneux alimentaires au Cameroun: diagnostic technique et stratégie de développement Honoré Tabuna et Ingratia Kayitavu.

72. Les exportateurs camerounais de safou (Dacryodes edulis) sur le marché sous régional et international: profil, fonctionnement et stratégies de développement.

73. Impact of the Southeast Asian Network for Agroforestry Education (SEANAFE) on agroforestry education capacity.

74. Setting landscape conservation targets and promoting them through compatible land use in the Philippines.

75. Review of methods for researching multistrata systems.

76. Study on economical viability of Jatropha curcas L. plantations in Northern Tanzania: assessing farmers' prospects via cost-benefit analysis.

77. Cooperation in agroforestry between Ministry of Forestry of Indonesia and International Centre for Research in Agroforestry.

78. China's bioenergy future: an analysis through the lens of Yunnan province.

79. Land tenure and agricultural productivity in Africa: a comparative analysis of the economics literature and recent policy strategies and reforms.

80. Boundary organizations, objects and agents: linking knowledge with action in agroforestry watersheds.

81. Reducing emissions from deforestation and forest degradation (REDD) in Indonesia: options and challenges for fair and efficient payment distribution mechanisms.

\section{9}

82. Mainstreaming climate change into agricultural education: challenges and perspectives.

83. Challenging conventional mindsets and disconnects in conservation: the emerging role of eco-agriculture in Kenya's landscape mosaics.

84. Lesson learned RATA garut dan bengkunat: suatu upaya membedah kebijakan pelepasan kawasan hutan dan redistribusi tanah bekas kawasan hutan.

85. The emergence of forest land redistribution in Indonesia.

86. Commercial opportunities for fruit in Malawi.

87. Status of fruit production processing and marketing in Malawi.

88. Fraud in tree science.

89. Trees on farms: analysis of global extent and geographical patterns of agroforestry.

90. The springs of Nyando: water, social organization and livelihoods in Western Kenya.

91. Building capacity toward region-wide curriculum and teaching materials development in agroforestry education in Southeast Asia.

92. Overview of biomass energy technology in rural Yunnan.

93. A pro-growth pathway for reducing net GHG emissions in China.

94. Analysis of local livelihoods from past to present in the central Kalimantan Ex-Mega Rice Project area. 
95. Constraints and options to enhancing production of high quality feeds in dairy production in Kenya, Uganda and Rwanda.

96. Agroforestry education in the Philippines: status report from the Southeast Asian Network for Agroforestry Education (Agroforestry education in the Philippines: status report from the Southeast Asian Network for Agroforestry Education (SEANAFE).

97. Economic viability of Jatropha curcas L. plantations in Northern Tanzania: assessing farmers' prospects via cost-benefit analysis.

98. Hot spot of emission and confusion: land tenure insecurity, contested policies and competing claims in the central Kalimantan Ex-Mega Rice Project area.

99. Agroforestry competences and human resources needs in the Philippines.

100. CES/COS/CIS paradigms for compensation and rewards to enhance environmental services.

101. Case study approach to region-wide curriculum and teaching materials development in agroforestry education in Southeast Asia.

102. Stewardship agreement to reduce emissions from deforestation and degradation (REDD): Lubuk Beringin's Hutan Desa as the first village forest in Indonesia.

103. Landscape dynamics over time and space from an ecological perspective.

104. A performance-based reward for environmental services: an action research case of "RiverCare" in Way Besai sub-watersheds, Lampung, Indonesia.

105. Smallholder voluntary carbon scheme: an experience from Nagari Paningahan, West Sumatra, Indonesia.

106. Rapid Carbon Stock Appraisal (RACSA) in Kalahan, Nueva Vizcaya, Philippines.

107. Tree domestication by ICRAF and partners in the Peruvian Amazon: lessons learned and future prospects in the domain of the Amazon Initiative eco-regional program.

108. Memorias del Taller Nacional: "Iniciativas para reducir la deforestación en la region Andino Amazónica", 9 de Abril del 2010. Proyecto REALU Peru.

109. Percepciones sobre la equidad y eficiencia en la cadena de valor de REDD en Perú: Reporte de Talleres en Ucayali, San Martín y Loreto, 2009. Proyecto REALU Perú.

110. Reducción de emisiones de todos los Usos del Suelo: reporte del Proyecto REALU Perú Fase 1.

111. Programa Alternativas a la Tumba-y-Quema (ASB) en el Perú: Informe Resumen y Síntesis de la Fase II. 2da. versión revisada.

112. Estudio de las cadenas de abastecimiento de germoplasma forestal en la amazonía Boliviana.

113. Biodiesel in the Amazon.

114. Estudio de mercado de semillas forestales en la amazonía Colombiana.

115. Estudio de las cadenas de abastecimiento de germoplasma forestal en Ecuador.

116. How can systems thinking, social capital and social network analysis help programs achieve impact at scale?

117. Energy policies, forests and local communities in the Ucayali Region, Peruvian Amazon. 
The World Agroforestry Centre is an autonomous, non-profit research organization whose vision is a rural transformation in the developing world where smallholder households strategically increase their use of trees in agricultural landscapes to improve their food security, nutrition, income, health, shelter, energy resources and environmental sustainability. The Centre generates science-base knowledge about the diverse role that trees play in agricultural landscapes, and uses its research to advance policies and practices that benefit the poor and the environment.

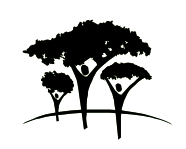

United Nations Avenue, Gigiri - PO Box 30677 - 00100 Nairobi, Kenya Tel: +254 207224000 or via USA +16508336645 Fax: +254 207224001 or via USA +1 6508336646

Southeast Asia Regional Program - Sindang Barang, Bogor 16115 PO Box 161 Bogor 16001, Indonesia

Tel: +62 2518625415 - Fax: +62 2518625416

www.worldagroforestry.org 